\title{
Persepsi Masyarakat Terhadap Vaksinasi Covid-19 Di Area Kerja Puskesmas Donggala
}

\author{
Virgiana $^{1}$, Abdul Munawwir ${ }^{1}$, Indah Puspasari Kiay Demak ${ }^{2}$ \\ ${ }^{1}$ Mahasiswa Profesi Dokter, Fakultas Kedokteran, Universitas Tadulako \\ ${ }^{2}$ Departemen Ilmu Kesehatan Masyarakat dan Kedokteran Komunitas, Fakultas \\ Kedokteran, Universitas Tadulako \\ ${ }^{3}$ Medical Education Unit, Fakultas Kedokteran, Universitas Tadulako
}

Author's Email Correspondence (*): anggivirgiana@gmail.com

Phone:+08521605989)

\begin{abstract}
ABSTRAK
Salah satu faktor yang memengaruhi lambatnya proses vaksinasi Covid-19 adalah adanya persepsi negatif masyarakat terhadap vaksin Covid-19. Penelitian ini bertujuan untuk mengetahui persepsi masyarakat terhadap vaksinasi Covid-19 di area kerja Puskesmas Donggala. Desain penelitian yang digunakan adalah deskriptif dengan pendekatan kuantitatif. Teknik pengambilan sampel berupa purposive sampling diperoleh 116 orang responden. Instrumen penelitian menggunakan kuesioner persepsi masyarakat terhadap vaksinasi Covid-19. Analisis data dilakukan secara deskriptif dari masing-masing variabel yang diteliti dengan tabel distribusi frekuensi disertai penjelasan. Hasil penelitian menunjukkan bahwa responden yang setuju untuk mendapatkan vaksinasi berdasarkan persepsi terkait keberhasilan tujuan vaksinasi berjumlah 76 orang $(65,5 \%)$, berdasarkan persepsi terkait keamanan vaksin berjumlah 71 orang $(61,2 \%)$, berdasarkan persepsi terkait efektivitas vaksin berjumlah 73 orang $(62,9 \%)$, dan berdasarkan persepsi terkait pandangan agama berjumlah 81 orang $(69,8 \%)$. Persepsi masyarakat terhadap vaksinasi Covid-19 sangat bervariasi dan berdasarkan persepsi tersebut diketahui bahwa rata-rata persentase responden yang setuju untuk mendapatkan vaksinasi adalah $64,7 \%$.
\end{abstract}

Kata Kunci: Persepsi masyarakat; vaksinasi covid-19; Puskesmas Donggala

Article histonshied by:

Received : 17TalRalako University

Received in revised form : 25Alddfesk:

Accepted : 3011.83eRdrno Hatta KM 9. Kota Palu, Sulawesi Tengah, Available online 3 II 1 armestia.

licensed by Creative Commons Attribution-ShareAlike 4.0 Internationhone: +628114120202

Email: Preventif.fkmuntad@gmail.com 


\begin{abstract}
One of the factors that affect the slow pace of the Covid-19 vaccination process is the negative public perception of the Covid-19 vaccine. This study aims to determine the public's perception of the Covid-19 vaccination in the Donggala Health Center work area. The research design used is descriptive with a quantitative approach. The sampling technique in the form of purposive sampling obtained 116 respondents. The research instrument used a questionnaire on public perceptions of the Covid-19 vaccination. Data analysis was carried out descriptively of each variable studied with a frequency distribution table accompanied by an explanation. The results showed that respondents who agreed to get vaccinated based on perceptions related to the success of the vaccination goal were 76 people (65.5\%), based on perceptions related to vaccine safety were 71 people $(61.2 \%)$, based on perceptions related to vaccine effectiveness were 73 people (62.9\%), and based on perceptions related to religious views, there were 81 people (69.8\%). Public perceptions of the Covid-19 vaccination vary widely and based on this perception it is known that the average percentage of respondents who agree to get vaccinated is $64.7 \%$.
\end{abstract}

Keywords : Public perception; covid-19 vaccination; Donggala Health Center

\title{
PENDAHULUAN
}

Pada bulan Desember 2019, Kota Wuhan, Provinsi Hubei, Cina, menjadi pusat wabah virus corona baru yang selanjutnya dikenal sebagai SARS-CoV-2 penyebab Covid-19. Virus ini menyebar dengan sangat cepat ke banyak negara melalui droplet atau cairan yang berasal dari alat pernapasan dan tersebar lewat kontak fisik antar manusia, seperti mulut, hidung, dan mata. Pemerintah Indonesia telah melakukan berbagai usaha guna memutus rantai penyebaran Covid-19 ini. Salah satu usaha yang dilakukan adalah menggiatkan proses vaksinasi Covid-19 secara massal untuk seluruh masyarakat Indonesia $(1,3)$

Vaksin adalah antigen berupa mikroorganisme yang sudah mati, masih hidup tapi dilemahkan, masih utuh atau bagiannya, yang telah diolah menjadi toksoid ataupun protein rekombinan yang apabila diberikan kepada seseorang akan menimbulkan kekebalan spesifik terhadap penyakit infeksi tertentu (4). Banyak upaya telah dikerahkan untuk pengembangan vaksin melawan Covid-19 untuk mencegah pandemi. Berdasarkan data WHO, lebih dari 200 jenis vaksin SARS-CoV-2 dalam proses pengembangan dan 6 di antaranya dalam uji klinis fase III yaitu vaksin AstraZeneca, Biotek Sinovac, Institut Biologi Wuhan Produk/Sinopharm, Beijing Institut Produk Hayati/ Sinopharm, Moderna/NIAID dan BioNTech/ Fosun Pharma/Pfizer (5,7). Terdapat beberapa tujuan vaksinasi Covid-19 yaitu menurunkan kesakitan dan kematian akibat Covid-19, mencapai kekebalan kelompok (herd immunity) untuk mencegah dan melindungi kesehatan masyarakat, melindungi dan memperkuat sistem 
kesehatan secara menyeluruh, dan menjaga produktifitas serta meminimalkan dampak sosial dan ekonomi (4).

Pada tanggal 13 Januari 2021, Presiden Joko Widodo merupakan orang pertama di Indonesia yang mendapatkan vaksinasi Covid-19. Sejak saat itu Pemerintah melakukan segala upaya untuk mempercepat proses vaksinasi nasional guna segera tercapainya kekebalan kelompok (herd immunity). Update data vaksinasi Covid-19 per 1 Juli 2021 sudah terdapat 30.184.392 orang yang telah menerima vaksinasi pertama dan 13.624.157 orang yang telah menerima vaksinasi kedua dari target sasaran vaksinasi nasional 181.554.465 orang, dari data tersebut diketahui bahwa dari bulan Maret 2021 sampai dengan Juli 2021 baru $7.5 \%$ dari target vaksinasi nasional yang telah lengkap mendapat vaksin (8).

Update data vaksinasi Covid-19 per 1 Juli 2021 di Provinsi Sulawesi Tengah, jumlah penerima vaksin pertama sebanyak 214.165 orang atau $45.30 \%$ dari target provinsi sedangkan jumlah penerima vaksin kedua sebesar 95.661 orang atau $20.23 \%$ dari target provinsi. Di Kabupaten Donggala, jumlah penerima vaksin pertama baru mencapai 7.707 orang atau $1.63 \%$ dari target provinsi sedangkan jumlah penerima vaksin kedua 3.306 orang atau $0.70 \%$ dari target provinsi (8).

Banyak faktor yang memengaruhi lambatnya proses vaksinasi, salah satunya adalah persepsi masyarakat. Persepsi didefinisikan sebagai aktivitas mengindera, mengintegrasikan dan memberikan penilaian pada objek fisik maupun objek sosial dan penginderaan tersebut tergantung pada stimulus yang ada di lingkungannya. Stimulus dari lingkungan akan diolah bersama dengan hal-hal yang telah dipelajari sebelumnya berupa harapan, nilai-nilai, sikap, ingatan dan lain-lain (9). Persepsi seseorang terkait suatu stimulus dapat berbeda dengan orang lainnya. Hal ini terjadi karena terdapat beberapa faktor yang memengaruhi persepsi, yaitu : (1) Faktor Psikologis terdiri dari (a) ekspektasi (mental set) yang dapat dipengaruhi oleh ketersediaan informasi sebelumnya, kebutuhan, dan pengalaman masa lalu; (b) emosi; dan (c) stimulus. (2) Faktor kebiasaan sosial, budaya, dan lingkungan fisik (11).

Berdasarkan latar belakang tersebut, maka perlu dilakukan penelitian terkait persepsi masyarakat terhadap vaksinasi Covid-19 yang meliputi persepsi keberhasilan tujuan vaksinasi, keamanan vaksin, efektivitas vaksin, dan pandangan agama terkait vaksin. Tujuan dari penelitian ini adalah untuk mengetahui persepsi masyarakat terhadap vaksinasi Covid-19 di area kerja Puskesmas Donggala. 


\section{METODE}

Penelitian ini menggunakan metode penelitian deskriptif dengan pendekatan kuantitatif. Penelitian dilakukan di area kerja Puskesmas Donggala pada bulan Juli s/d Agustus 2021. Populasi pada penelitian ini adalah seluruh masyarakat di area kerja Puskesmas Donggala yang menjadi target vaksinasi. Menggunakan teknik pengambilan sampel berupa purposive sampling dengan mempertimbangkan kriteria inklusi dan eksklusi, terdapat 116 orang responden yang turut serta pada penelitian ini.

Pengumpulan data dilakukan dengan menyebarkan kuesioner persepsi masyarakat terhadap vaksinasi Covid-19. Kuesioner memiliki 20 pertanyaan yang terbagi dalam 4 variabel penelitian yaitu keberhasilan tujuan vaksinasi, keamanan vaksin, efektivitas vaksin, dan pandangan agama yang diyakini responden. Seluruh data yang diperoleh dan dikumpulkan dari penelitian kemudian dilakukan analisis secara deskriptif dari masingmasing variabel yang diteliti dan penyajian data menggunakan tabel distribusi frekuensi disertai penjelasan. 
HASIL

Tabel 1

Karakteristik Responden

\begin{tabular}{|c|c|c|}
\hline Karakteristik Responden & $\mathbf{n}$ & $\%$ \\
\hline \multicolumn{3}{|l|}{ Jenis Kelamin } \\
\hline Laki-laki & 41 & 35,3 \\
\hline Perempuan & 75 & 64,7 \\
\hline Usia & 23 & 19,8 \\
\hline $17-25$ Tahun & 37 & 31,9 \\
\hline 26 - 35 Tahun & 30 & 25,9 \\
\hline 36 - 45 Tahun & 23 & 19,8 \\
\hline 46 - 55 Tahun & 3 & 2,6 \\
\hline \multicolumn{3}{|l|}{$56-65$ Tahun } \\
\hline Agama & 112 & 96,6 \\
\hline Islam & 4 & 3,4 \\
\hline \multicolumn{3}{|l|}{ Kristen } \\
\hline \multicolumn{3}{|l|}{ Pendidikan } \\
\hline SD & 3 & 2,6 \\
\hline SMP & 6 & 5,2 \\
\hline SMA & 43 & 37,1 \\
\hline D3 & 5 & 4,3 \\
\hline $\mathrm{D} 4 / \mathrm{S} 1$ & 52 & 44,8 \\
\hline S2 & 7 & 6,0 \\
\hline Pekerjaan & 24 & 20,7 \\
\hline Honorer & 29 & 25,0 \\
\hline PNS & 22 & 19,0 \\
\hline IRT & 18 & 15,5 \\
\hline Dosen / Guru & 9 & 7,8 \\
\hline Pelajar / Mahasiswa & 10 & 8,6 \\
\hline Wiraswasta & 4 & 3,4 \\
\hline Petani & & \\
\hline
\end{tabular}

Berdasarkan Tabel 1 menunjukkan bahwa distribusi responden menurut jenis kelamin terbanyak adalah perempuan dengan jumlah 75 orang responden $(64,7 \%)$ dan yang terendah adalah laki-laki dengan jumlah 41 orang responden (35,3\%). Distribusi responden menurut kelompok usia terbanyak adalah kelompok usia 26 - 35 tahun yaitu sebanyak 37 orang responden $(31,9 \%)$ dan yang terendah pada kelompok usia 56 - 65 tahun yaitu sebanyak 3 
orang responden $(2,6 \%)$. Distribusi responden menurut kelompok agama terbanyak adalah kelompok agama Islam yaitu sebanyak 112 orang responden (96,6\%) dan yang terendah pada kelompok agama Kristen yaitu sebanyak 4 orang responden (3,4\%). Distribusi responden menurut kelompok pendidikan terbanyak adalah kelompok D4/S1 yaitu sebanyak 52 orang $(44,8 \%)$ dan yang terendah pada kelompok SD yaitu sebanyak 3 orang responden $(2,6 \%)$. Sementara itu, distribusi responden menurut kelompok pekerjaan terbanyak adalah kelompok PNS yaitu sebanyak 29 orang responden $(25,0 \%)$ dan yang terendah pada kelompok Petani yaitu sebanyak 4 orang responden dari 116 orang total responden $(3,4 \%)$.

Tabel 2

Persepsi Masyarakat Terkait Keberhasilan Vaksinasi

\begin{tabular}{|c|c|c|c|c|}
\hline Persepsi Masyarakat & $\mathbf{S}$ & $\%$ & TS & $\%$ \\
\hline Vaksinasi Covid-19 dapat mengurangi penularan & 82 & $70,7 \%$ & 34 & $29,3 \%$ \\
\hline $\begin{array}{l}\text { Vaksinasi Covid-19 dapat menurunkan angka } \\
\text { kesakitan }\end{array}$ & 79 & $68,1 \%$ & 37 & $31,9 \%$ \\
\hline Vaksinasi Covid-19 dapat mengurangi kematian & 64 & $55,2 \%$ & 52 & $44,8 \%$ \\
\hline $\begin{array}{l}\text { Vaksinasi Covid-19 dapat menimbulkan kekebalan } \\
\text { kelompok di masyarakat (herd immunity) }\end{array}$ & 79 & $68,1 \%$ & 37 & $31,9 \%$ \\
\hline $\begin{array}{l}\text { Vaksinasi Covid-19 dapat melindungi masyarakat } \\
\text { agar tetap produktif secara sosial dan ekonomi }\end{array}$ & 79 & $68,1 \%$ & 37 & $31,9 \%$ \\
\hline $\begin{array}{l}\text { Kesediaan menerima vaksinasi Covid-19 } \\
\text { berdasarkan persepsi masyarakat terkait keberhasilan } \\
\text { tujuan vaksinasi }\end{array}$ & 76 & $65,5 \%$ & 40 & $34,5 \%$ \\
\hline
\end{tabular}

Sumber : Data Primer, 2021

Berdasarkan Tabel 2 menunjukkan bahwa responden yang setuju untuk mendapatkan vaksinasi berdasarkan persepsi masyarakat terkait keberhasilan tujuan vaksinasi berjumlah 76 orang responden $(65,5 \%)$ dan yang tidak setuju sebanyak 40 orang responden $(34,5 \%)$. Hal ini didasari oleh persepsi masyarakat terkait keberhasilan tujuan tersebut belum maksimal. Masyarakat yang setuju bahwa vaksinasi dapat mengurangi penularan hanya 70,7\%, mengurangi angka kematian 55,2\% dan menurunkan angka kesakitan, menimbulkan herd immunity, serta melindungi masyarakat tetap produktif secara social ekonomi masing-masing $68,1 \%$. 
Tabel 3

Persepsi Masyarakat Terkait Keamanan Vaksin

\begin{tabular}{|c|c|c|c|c|}
\hline Persepsi Masyarakat & $\mathbf{S}$ & $\%$ & TS & $\%$ \\
\hline Vaksin Covid-19 sudah mendapatkan izin edar BPOM & 97 & $83,6 \%$ & 19 & $16,4 \%$ \\
\hline $\begin{array}{l}\text { Vaksin Covid-19 tidak aman karena dikembangkan } \\
\text { dalam jangka waktu yang sangat cepat }\end{array}$ & 40 & $34,5 \%$ & 76 & $65,5 \%$ \\
\hline $\begin{array}{l}\text { Vaksinasi Covid-19 menyebabkan seseorang terinfeksi } \\
\text { virus corona }\end{array}$ & 29 & $25,0 \%$ & 87 & $75,0 \%$ \\
\hline $\begin{array}{l}\text { Vaksin Covid-19 mengandung racun dan } \\
\text { menyebabkan efek samping berlebihan }\end{array}$ & 19 & $14,7 \%$ & 99 & $85,3 \%$ \\
\hline $\begin{array}{l}\text { Pemberian vaksin Covid-19 dapat menyebabkan } \\
\text { kematian }\end{array}$ & 24 & $20,7 \%$ & 92 & $79,3 \%$ \\
\hline $\begin{array}{l}\text { Kesediaan menerima vaksinasi Covid-19 berdasarkan } \\
\text { persepsi masyarakat terkait keamanan vaksin }\end{array}$ & 71 & $61,2 \%$ & 45 & $38,8 \%$ \\
\hline
\end{tabular}

Tabel 3 menunjukkan bahwa jika ditinjau dari persepsi masyarakat terkait keamanan vaksin, hanya $61,2 \%$ dari total responden yang setuju untuk menerima vaksinasi, sedangkan $38,8 \%$ lainnya menolak. Hal ini dipengaruhi oleh adanya anggapan negatif terkait vaksin yang beredar. Sebanyak 16,4\% responden belum mengetahui bahwa vaksin Covid-19 telah mendapat izin edar dari BPOM, 34,5\% responden beranggapan bahwa vaksin Covid-19 tidak aman karena dikembangkan dalam waktu yang sangat cepat. $25 \%$ responden setuju vaksinasi dapat menyebabkan seseorang terinfeksi virus corona. $14,7 \%$ responden menyatakan vaksin Covid-19 mengandung racun yang berbahaya, dan 20,7\% percaya pemberian vaksin dapat menyebabkan kematian.

Tabel 4

Persepsi Masyarakat Terkait Efektivitas Vaksin

\begin{tabular}{|c|c|c|c|c|}
\hline Persepsi Masyarakat & $\mathbf{S}$ & $\%$ & TS & $\%$ \\
\hline $\begin{array}{l}\text { Vaksin Covid-19 efektif dalam mencegah penularan } \\
\text { Covid-19 }\end{array}$ & 81 & $69,8 \%$ & 35 & $30,2 \%$ \\
\hline $\begin{array}{l}\text { Vaksin Covid-19 efektif melindungi kita dalam jangka } \\
\text { waktu panjang }\end{array}$ & 77 & 66,4 & 39 & $33,6 \%$ \\
\hline $\begin{array}{l}\text { Pemberian vaksin Covid-19 harus dilakukan sebanyak } \\
2 \text { kali untuk memaksimalkan efektivitas }\end{array}$ & 87 & $75,0 \%$ & 29 & $25,0 \%$ \\
\hline $\begin{array}{l}\text { Jenis vaksin yang tersedia di Indonesia belum efektif } \\
\text { untuk seluruh mutasi virus corona }\end{array}$ & 48 & $41,4 \%$ & 68 & $58,6 \%$ \\
\hline $\begin{array}{l}\text { Kesediaan menerima vaksinasi berda } \\
\text { masyarakat terkait efektivitas vaksin }\end{array}$ & 73 & 62 & 43 & 37, \\
\hline
\end{tabular}

Sumber : Data Primer, 2021 
Tabel 4 menunjukkan sebanyak 69,8\% responden setuju vaksin efektif dalam mencegah penularan Covid-19, 66,4\% responden setuju perlindungan vaksin efektif dalam jangka waktu panjang, 75\% responden setuju pemberian vaksin harus diberikan sebanyak 2 kali untuk memaksimalkan efektivitas. Namun, terdapat $41,4 \%$ responden yang menyatakan bahwa vaksin yang tersedia di Indonesia belum efektif. Berdasarkan persepsi ini, secara keseluruhan hanya $62,9 \%$ dari total responden yang setuju menerima vaksinasi Covid-19 dan 37,1\% lainnya menolak.

\section{Tabel 5}

Persepsi Masyarakat Terkait Pandangan Agama

\begin{tabular}{|c|c|c|c|c|}
\hline Persepsi Masyarakat & $\mathbf{S}$ & $\%$ & TS & $\%$ \\
\hline $\begin{array}{l}\text { Vaksin Covid-19 sudah mendapatkan sertifikat halal dari } \\
\text { MUI }\end{array}$ & 103 & $88,8 \%$ & 13 & $11,2 \%$ \\
\hline $\begin{array}{l}\text { Pemberian Vaksin Covid-19 bertentangan dengan } \\
\text { keyakinan agama saya }\end{array}$ & 26 & $22,4 \%$ & 90 & $77,6 \%$ \\
\hline $\begin{array}{l}\text { Kesediaan menerima vaksinasi berdasarkan persepsi } \\
\text { masyarakat terkait pandangan agama }\end{array}$ & 81 & $69,8 \%$ & 35 & $30,2 \%$ \\
\hline
\end{tabular}

Berdasarkan Tabel 5 diketahui bahwa terkait pandangan agama, 69,8\% dari total responden setuju untuk menerima vaksinasi dan 30,2\% menyatakan penolakannya. Hal ini didasari oleh sebanyak 11,2\% responden belum mengetahui bahwa vaksin Covid-19 telah mendapatkan sertifikat halal dari MUI dan 22,4\% menyatakan pemberian vaksin bertentangan dengan keyakinan agama yang dianutnya.

\section{PEMBAHASAN}

Berdasarkan hasil penelitian yang diperoleh, diketahui bahwa persepsi masyarakat terhadap vaksinasi Covid 19 sangat bervariasi yang dinilai berdasarkan keberhasilan tujuan vaksinasi, keamanan vaksin, efektivitas vaksin, dan pandangan agama terkait vaksinasi. Persepsi inilah yang memengaruhi kesediaan masyarakat dalam menerima vaksinasi Covid 19. Adanya persepsi negatif dari masyarakat menyebabkan penolakan terhadap proses vaksinasi. Hal ini sesuai dengan hasil penelitian yang telah dilakukan sebelumnya menyatakan bahwa persepsi masyarakat merupakan faktor penting yang memengaruhi upaya

kesehatan dan pencegahan penyakit. Lebih lanjut disebutkan bahwa salah satu faktor yang memengaruhi lambatnya proses vaksinasi di Indonesia adalah persepsi masyarakat (11).

Beberapa responden yang turut serta dalam penelitian ini, masih ragu terhadap keberhasilan tujuan vaksinasi yang diinformasikan oleh pemerintah. Menurut responden 
belum ada bukti nyata bahwa pemberian vaksin dapat menurunkan angka penularan, kesakitan, dan angka kematian, serta menimbulkan kekebalan kelompok. Bahkan, terdapat beberapa orang yang tetap terinfeksi virus corona walaupun telah mendapatkan dosis vaksinasi yang lengkap. Hal yang mendasari adanya persepsi ini adalah kurangnya pengetahuan tentang vaksin dan tujuannya. Padahal Satgas Covid-19 pada tahun 2021 menyatakan bahwa vaksin tidak $100 \%$ membuat orang yang telah divaksin kebal terhadap Covid-19 sehingga tetap harus mematuhi dan menjalankan protokol kesehatan 5M. Namun, apabila tetap terjadi infeksi setelah pemberian angka kesakitan dan kematiannya jauh lebih rendah dibanding mereka yang tidak melakukan vaksinasi.

Pada penelitian ini, diketahui bahwa masih cukup banyak responden yang beranggapan jika vaksin COVID 19 yang beredar tidak aman, mengandung racun dan dapat menyebabkan seseorang justru terinfeksi virus corona bahkan menyebabkan kematian, sehingga efektivitas vaksin masih diragukan. Berdasarkan keterangan responden, informasi ini dapat dipercaya karena sangat banyak dibicarakan di kalangan masyarakat serta telah banyak bukti yang tersebar di sosial media. Hal ini menimbulkan ketakutan dan berujung pada penolakan untuk mendapatkan vaksinasi. Hasil ini sesuai dengan teori yang menyatakan bahwa persepsi masyarakat yang akhirnya akan memberikan penilaian dan tanggapan pada suatu objek sangat tergantung pada stimulus yang ada di lingkungan, karena stimulus inilah yang akan diolah bersama dengan hal-hal yang telah dipelajari sebelumnya berupa harapan, nilai-nilai, sikap, ingatan dan lain-lain (9).

Hasil yang serupa diperoleh pada survey yang dilakukan oleh Kemenkes RI tahun 2021 yang menyebutkan bahwa banyak masyarakat yang percaya jika kondisi pandemi saat ini merupakan produk propaganda, konspirasi, hoaks, dan/atau upaya sengaja untuk memperoleh keuntungan bagi oknum tertentu. Informasi-informasi inilah yang terus beredar di kalangan masyarakat sehingga memengaruhi persepsi dan penerimaan masyarakat terhadap vaksin Covid-19. ${ }^{(11)}$ Suatu literature review menunjukkan bahwa tingkat kecemasan dan keraguan masyarakat yang menyebabkan adanya persepsi buruk terkait kegiatan vaksinasi Covid-19 bermula dari tidak adanya komunikasi yang efektif maupun edukasi dari layanan kesehatan

untuk masyarakat sehingga banyak berita hoax yang beredar dan membuat masyarakat takut untuk mendapatkan vaksin (12).

Alasan penolakan lainnya terhadap vaksin COVID 19 adalah adanya keraguan terkait kehalalan vaksin. Padahal pada tanggal 11 Januari dan 16 Maret 2021, Komisi Fatwa Majelis Ulama Indonesia (MUI) Pusat menetapkan bahwa vaksin Covid-19 yang diproduksi oleh 
Sinovac Life Sciences Co. Ltd. China dan PT. Bio Farma (Persero) hukumnya suci dan halal sehingga boleh digunakan untuk umat Islam sepanjang terjamin keamanannya menurut ahli yang kredibel dan kompeten. Sementara itu, vaksin produksi Astra Zeneca hukumnya haram karena dalam proses produksinya terdapat penggunaan tripsin babi. Namun melihat kondisi yang ada, vaksin produksi Astra Zeneca ini menjadi mubah karena darurat $(13,14)$

Jika ditinjau dari karakteristik usia responden pada penelitian ini, diketahui bahwa penolakan terhadap vaksinasi sebagian besar terjadi pada responden kelompok usia 17-45 tahun. Hasil yang sama diperoleh pada penelitian sebelumnya yang menemukan bahwa pada kelompok usia yang lebih muda terdapat kecenderungan untuk tidak atau belum bersedia divaksinasi. Dengan kata lain, semakin tua umur semakin tinggi pula kesediaan untuk menerima vaksinasi. Padahal peningkatan proporsi insiden Covid-19 terjadi pada usia muda sehingga peran dalam penyebaran penyakit selama epidemi semakin meningkat. Oleh karena itu, menargetkan intervensi vaksin untuk mencegah penularan kepada orang dewasa berusia 20 hingga 49 tahun merupakan pertimbangan penting dalam menghentikan epidemi yang muncul kembali dan mencegah kematian akibat Covid-19 (15).

Berdasarkan karakteristik tingkat pendidikan, penolakan terhadap vaksin cukup besar terjadi pada responden lulusan D4/S1. Salah satu alasan yang mendasari hal ini adalah anggapan bahwa upaya yang telah dilakukan untuk mencegah covid 19 seperti mencuci tangan, menggunakan masker, menjaga jarak, dan tetap di rumah sudah cukup untuk menghentikan penyebaran. Dengan demikian, penggunaan vaksin belum dibutuhkan. Hal ini dijelaskan oleh teori yang menyebutkan bahwa salah satu hal yang memengaruhi persepsi seseorang adalah tingkat kebutuhan karena seseorang cenderung memersepsikan sesuatu berdasarkan kebutuhannya saat itu (10). Hasil penelitian ini serupa dengan hasil yang diperoleh sebelumnya bahwa terdapat kecenderungan semakin rendah pendidikan responden maka semakin tinggi tingkat kesediaan untuk menerima vaksinasi. Sementara itu, responden dengan tingkat pendidikan tinggi lebih cenderung menolak vaksinasi (15).

\section{KESIMPULAN DAN SARAN}

Persepsi masyarakat terhadap vaksinasi Covid 19 sangat bervariasi yang dinilai berdasarkan keberhasilan tujuan vaksinasi, keamanan vaksin, efektivitas vaksin, dan pandangan agama terkait vaksinasi. Persepsi inilah yang memengaruhi kesediaan masyarakat 
dalam menerima vaksinasi Covid 19. Adanya persepsi negatif dari masyarakat menyebabkan penolakan terhadap proses vaksinasi. Berdasarkan hasil penelitian, diketahui bahwa rata-rata persentase responden yang setuju untuk mendapatkan vaksinasi adalah 64,7\%. Secara keseluruhan, kelompok yang belum bersedia untuk mendapatkan vaksinasi Covid-19 dapat menjadi sasaran edukasi. Melalui kegiatan edukasi ini, diharapkan dapat memberikan informasi yang memadai dan bukti penelitian berbasis ilmiah untuk mengedukasi masyarakat sehingga dapat mengurangi tersebarnya informasi-informasi palsu terkait vaksin Covid-19. Hal ini diharapkan dapat meningkatkan kesediaan masyarakat untuk menerima vaksinasi.

\section{DAFTAR PUSTAKA}

1. Ouassou H, Kharchoufa L, Bouhrim M, Daoudi NE, Imtara H, Bencheikh N, et al. The Pathogenesis of Coronavirus Disease 2019 (COVID-19): Evaluation and Prevention. Journal of Immunology Research. 2020 Jul 10;2020:1-7.

2. Shi Y, Wang G, Cai X, Deng J, Zheng L, Zhu H, et al. An Overview of COVID-19. J Zhejiang Univ Sci B. 2020 May;21(5):343-60.

3. Muhammad FF, Yulitania I, Putri MPO, Shihab M. Pembentukan Persepsi Mahasiswa Program Studi Ilmu Komunikasi President University tentang Vaksinasi COVID-19. $2021 ; 11$.

4. Kementerian Kesehatan RI. Peraturan Menteri Kesehatan Republik Indonesia Nomor 10 Tahun 2021 Tentang Pelaksanaan Vaksinasi Dalam Rangka Penanggulangan Pandemi Corona Virus Disease 2019. 2021.

5. Kaur SP, Gupta V. COVID-19 Vaccine: A comprehensive status report. Virus Research. 2020 Oct;288:198114.

6. Haynes BF, Corey L, Fernandes P, Gilbert PB, Hotez PJ, Rao S, et al. Prospects For A Safe COVID-19 Vaccine. Sci Transl Med. 2020 Nov 4;12(568):eabe0948.

7. Yuningsih R. The Coronavac Clinical Trial And The Plan For Mass Covid-19 Vaccination In Indonesia. : 6.

8. Dinas Kesehatan Provinsi Sulawesi Tengah. Capaian Harian Vaksinasi Covid-19 di Sulawesi Tengah [Internet]. 2021. Available from: dinkes.sultengprov.go.id

9. Fitri NK. Persepsi Dan Perilaku Masyarakat Dalam Pencegahan Transmisi Covid-19 Di Kota Medan, Sumatera Utara. SKRIPSI. :117.

10. Jayanti F, Arista NT. Persepsi Mahasiswa Terhadap Pelayanan Perpustakaan Universitas Trunojoyo Madura. Kompetensi. Available from: https://journal.trunojoyo.ac.id/kompetensi/article/view/4958

11. Kementerian Kesehatan RI. Survei Penerimaan Vaksin Covid-19 di Indonesia. 2020 Nov; Available from: Covid19.go.id

12. Astuti NP, Nugroho EGZ, Lattu JC, Potempu IR, Swandana DA. Persepsi Masyarakat Terhadap Penerimaan Vaksinasi Covid-19: 2021;13(3):12. 
13. Majelis Ulama Indonesia. Fatwa MUI Nomor 2 Tahun 2021 Tentang Produk Vaksin Covid-19 dari Sinovac Life Sciens Co. Ltd. China dan PT Bio Farma (Persero) [Internet]. 2021. Available from: mui.or.id

14. Majelis Ulama Indonesia. Fatwa MUI Nomor 14 Tahun 2021 Tentang Hukum Penggunaan Vaksin Covid-19 Produk Astrazeneca [Internet]. 2021. Available from: mui.or.id

15. Ichsan DS, Hafid F, Ramadhan K, Taqwin T. Determinan Kesediaan Masyarakat menerima Vaksinasi Covid-19 di Sulawesi Tengah. JIK. 2021 May 26;15(1):1-11. 